\title{
CHEMICAL COMPOSITION OF BIOTITES AS A GUIDE TO ASCERTAIN THE ORIGIN OF GRANITES
}

\author{
N. W. Gokhale \\ Karnatak University, Dharwar 3, India
}

\begin{abstract}
Biotites occurring in igneous and metamorphic-metasomatic rocks have been critically studied. The study reveals a marked difference between the chemical composition of biotites from igneous rocks on one hand and those from metamorphic-metasomatic ones on the other. It is concluded that the chemical composition of a biotite reflects the environment of its formation as well as that of the rock containing it. The most frequently occurring ferromagnesian mineral in granites is biotite. As such it is thought that by processing the chemical data as suggested in this paper it should be possible to distinguish between granites formed by more than one mode of origin.
\end{abstract}

\section{Introduction}

It has been agreed upon by petrologists that the crystalline rocks have originated under two environments namely, magmatic and metamorphic-metasomatic. This is especially true of granitic rocks (Gorai 1951, Tertsch 1941, 1942, Turner 1951). Various criteria have been proposed to indicate the magmatic and metamorphicmetasomatic origin of crystalline rocks. One such approach is to study the minerals of these rocks. In this paper emphasis is laid on granites, since the origin of these rocks is a matter of great dispute. Besides other minerals, biotite is one which is more often studied, since it is the most frequently occurring ferromagnesian mineral in granites. Heinrich, Nockolds, Hall, Peikert and others have studied the chemical compositions and/or the R.I. of the biotites occurring in various rocks and they have drawn certain conclusions. Heinrich has interconnected the chemical composition of the biotite and its geological occurrence. Based on his studies, he has recognised eight groups of rocks namely -
1. granite pegmatites.

2. granites, quartz-monzonites, granodiorites.

3. tonalites and diorites.

4. gabbros.

5. peridotites and other ultramafic rocks.

6. syenites, nepheline syenites and syenite pegmatites.

7. gneisses and schists.

8. metamorphosed limestones.

Heinrich, however has not made a distinction between the igneous granites and the metamorphic-metasomatic granites. He has also not studied the behaviour of biotites from charnockites.

Nockolds has studied the micas occurring in the calc-alkali and the alkali igneous rocks. He has arrived at the conclusion that the chemical composition of biotites is a function of the associated ferromagnesian minerals occurring in that rock. He did not extend his theory to the biotites occurring in the metamorphic-metasomatic rocks. 
Peikert has successfully demonstrated the interdependence of the R.I. of a biotite and its Fe: $\mathrm{Mg}$ ratio. By studying the areal distribution of the R.I. values of biotites, he has come to the conclusion that the granitic rocks containing them are of metasomatic origin.

Though in the studies referred to above, biotite has been used to indicate the petrogenetic conditions of rock formation, the studies have not been extended to distinguish between identical crystalline rocks resulting from more than one petrogenetic process. In view of this, the author desirous of working further on biotites in respect of the chemical compositions of biotites as an indicator of environment of the formation of the rock in which they occur, selected a number of chemical analyses of biotites from the literature. They were processed in order to plot them on different diagrams and to establish whether there is any systematic behaviour of these plots. The behaviour of these plots and their usefulness in knowing the environment of formation of the rocks in which they occur, is discussed in this paper.

\section{Methodology and materials used}

The chemical analyses of biotites used for the present study have been taken from Nockolds (1947), Naik (1965), Peikert (1963), Deer et al (1962), Machigad (1967), and Gokhale (1967). These biotites are from calc-alkali granites, alkali granites, potassic granites, acid charnockites and from metamorphic schists and gneisses. The processed chemical data have been plotted on three types of variation diagrams: one after Heinrich, wherein $\mathrm{Fe}_{2} \mathrm{O}_{3}+\mathrm{TiO}_{2}: \mathrm{MgO}: \mathrm{FeO}$ $+\mathrm{MnO}$ values are taken into account; another after Nockolds in which $\mathrm{Al}_{2} \mathrm{O}_{3}, \mathrm{MgO}$ and total iron as $\mathrm{FeO}$ are selected as the critical constituents and the third one proposed by the present author, wherein $\mathrm{SiO}_{2}, \mathrm{~K}_{2} \mathrm{O}$ and $\mathrm{Na}_{2} \mathrm{O}$ are taken as the coordinates. In these calculations 49 biotite analyses are used, the details of which are as under:
10 analyses from metamorphic-metasomatic granites

(Peikert and Naik)

$6 \ldots$ do ...... acid charnockites of metamorphic origin (Machigad)

$16 \ldots$ do ....... schists and gneisses

(Deer et al)

$17 \ldots$ do ...... igneous granites (Gokhale, Nockolds, Deer et al)

The calculated values are tabulated in table 1.

\section{Description of variation diagrams}

Diagram 1

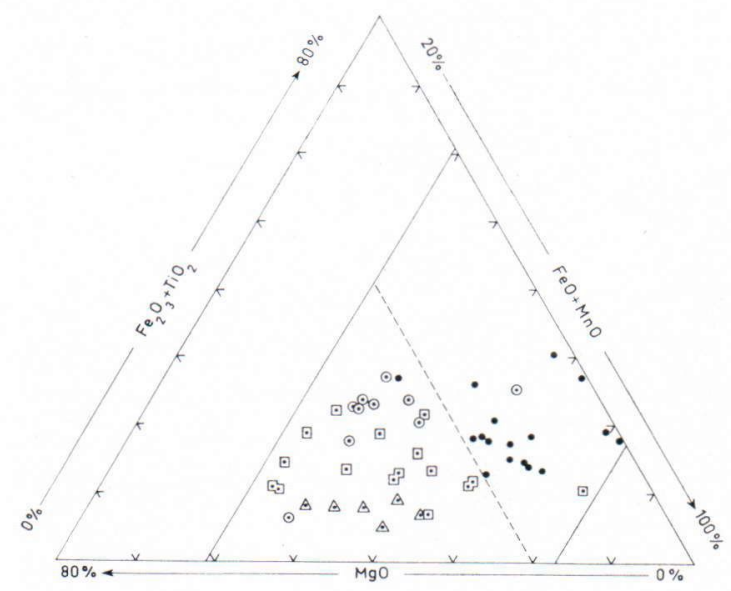

- Biotites from igneous rocks: calc-alkali, alkali \& potassic granites.

- Biotites from metamorphic-metasomatic rocks: granites.

- Biotites from metamorphic-metasomatic rocks: schists \& gneisses.

Biotites from metamorphic-metasomatic rocks: acid charnokites.

Zone drawn as per Heinrich.

Separates biotites of magmatic environment from those of metamorphic-metasomatic environment.

This has been constructed on the lines as suggested by Heinrich. He has demarcated the field of plutonic biotites from that of the volcanic 
TABLE 1

\begin{tabular}{|c|c|c|c|c|c|c|c|c|c|}
\hline \multirow{2}{*}{$\frac{\text { Biotite }}{\text { from }}$} & \multicolumn{3}{|c|}{ HEINRICH VALUES } & \multicolumn{3}{|c|}{ NOCKOLDS VALUES } & \multicolumn{3}{|c|}{ GOKHALE VALUES } \\
\hline & $\mathrm{FeO}+\mathrm{MnO}$ & $\mathrm{Fe}_{2} \mathrm{O}_{3}+\mathrm{TiO}_{2}$ & $\mathrm{MgO}$ & $\mathrm{Al}_{2} \mathrm{O}_{3}$ & $\mathrm{MgO}$ & Total iron & $\mathrm{SiO}_{2}$ & $\mathrm{~K}_{2} \mathrm{O}$ & $\mathrm{Na}_{2} \mathrm{O}$ \\
\hline 1. & 26.10 & 40.03 & 33.87 & 42.10 & 21.81 & 36.08 & 79.61 & 14.86 & 5.53 \\
\hline 2. $\bigotimes_{\infty}^{\infty}$ & 44.66 & 21.27 & 34.06 & 36.07 & 24.45 & 39.48 & 79.49 & 19.70 & 0.81 \\
\hline 3. $\frac{\infty}{d}$ & 65.91 & 11.61 & 22.48 & 37.36 & 15.31 & 47.33 & 79.09 & 19.99 & 0.92 \\
\hline 4. Еू & 56.17 & 12.71 & 31.12 & 40.18 & 20.07 & 39.75 & 80.44 & 19.16 & 0.40 \\
\hline 5. 7 & 49.95 & 13.04 & 37.01 & 41.21 & 23.93 & 34.85 & 79.96 & 19.69 & 0.35 \\
\hline 6. छี & 57.28 & 16.29 & 26.42 & 37.00 & 18.03 & 44.97 & 77.56 & 21.40 & 1.04 \\
\hline 7. & 63.30 & 6.35 & 30.35 & 40.64 & 18.92 & 40.44 & 81.04 & 18.01 & 0.97 \\
\hline 8. $\stackrel{\stackrel{\omega}{n}}{=}$ & 41.03 & 15.01 & 43.96 & 42.02 & 27.33 & 30.64 & 80.48 & 16.83 & 2.69 \\
\hline 9. 릉 & 51.49 & 18.41 & 30.10 & 40.39 & 20.28 & 39.33 & 78.49 & 20.62 & 0.89 \\
\hline 10. & 41.86 & 18.84 & 39.30 & 38.23 & 28.82 & 32.94 & 80.62 & 19.23 & 0.15 \\
\hline 11. & 60.30 & 13.45 & 26.25 & 40.68 & 16.74 & 42.58 & 78.18 & 21.35 & 0.47 \\
\hline 12. & 65.52 & 11.67 & 22.80 & 41.70 & 14.55 & 43.75 & 78.54 & 19.32 & 2.14 \\
\hline 13. 이 & 56.79 & 10.97 & 32.23 & 42.64 & 20.57 & 36.79 & 79.08 & 20.08 & 0.84 \\
\hline 14. त्త్ & 55.53 & 21.33 & 23.14 & 42.51 & 15.94 & 41.55 & 79.77 & 18.70 & 1.53 \\
\hline 15. & 42.54 & 10.00 & 47.46 & 50.43 & 25.69 & 23.88 & 81.92 & 16.66 & 1.42 \\
\hline 16. & 81.71 & 10.39 & 7.90 & 34.03 & 5.45 & 60.51 & 78.30 & 21.39 & 0.31 \\
\hline 17. & 65.00 & 17.69 & 17.31 & 36.92 & 12.46 & 50.61 & 78.54 & 20.14 & 1.32 \\
\hline 18. & 74.85 & 12.90 & 12.25 & 34.76 & 9.02 & 56.20 & 81.10 & 17.75 & 1.15 \\
\hline 19. & 59.73 & 25.53 & 14.74 & 37.97 & 10.35 & 51.68 & 81.87 & 16.76 & 1.37 \\
\hline 20. & 49.80 & 26.37 & 23.83 & 37.56 & 18.36 & 44.09 & 80.23 & 18.33 & 1.44 \\
\hline 21. & 69.50 & 14.90 & 15.60 & 30.94 & 12.14 & 57.82 & 79.36 & 19.47 & 1.17 \\
\hline 22. \& & 72.40 & 14.40 & 13.20 & 29.78 & 10.39 & 59.84 & 79.47 & 19.59 & 0.94 \\
\hline 23. & 71.58 & 14.67 & 13.76 & 31.03 & 10.78 & 58.19 & 78.77 & 20.65 & 0.57 \\
\hline 24. तु & 79.68 & 19.32 & 1.01 & 34.31 & 0.71 & 64.98 & 80.66 & 15.75 & 3.58 \\
\hline 25. & 72.63 & 27.28 & 0.12 & 24.06 & 0.01 & 75.84 & 76.17 & 20.17 & 3.67 \\
\hline 26. & 63.78 & 17.60 & 18.62 & 42.40 & 11.57 & 46.03 & 78.21 & 20.85 & 0.92 \\
\hline 27. @ & 64.36 & 17.84 & 17.80 & 43.04 & 11.13 & 45.83 & 79.66 & 19.12 & 1.22 \\
\hline 28. & 64.76 & 20.82 & 14.42 & 41.53 & 9.36 & 49.11 & 80.05 & 18.95 & 0.99 \\
\hline 29. & 67.67 & 12.53 & 19.80 & 40.67 & 13.32 & 46.03 & 77.80 & 21.38 & 0.82 \\
\hline 30. & 70.78 & 18.11 & 11.13 & 29.77 & 8.62 & 61.62 & 81.56 & 18.10 & 0.33 \\
\hline 31. & 67.13 & 30.40 & 2.47 & 25.46 & 2.05 & 72.49 & 77.02 & 19.63 & 3.35 \\
\hline 32. & 81.87 & 17.52 & 0.61 & 26.67 & 0.49 & 72.86 & 80.28 & 18.86 & 0.84 \\
\hline 33. & 68.06 & 16.96 & 14.98 & 31.09 & 11.53 & 57.38 & 88.94 & 10.28 & 0.75 \\
\hline 34. & 46.75 & 23.84 & 29.40 & 35.44 & 20.85 & 43.71 & 82.53 & 16.73 & 0.74 \\
\hline 35. & 47.90 & 17.36 & 34.74 & 34.50 & 24.57 & 40.93 & 81.39 & 18.14 & 0.47 \\
\hline 36. छ. & 46.89 & 22.12 & 30.99 & 34.03 & 22.39 & 43.58 & 82.42 & 17.14 & 0.44 \\
\hline 37. 总 & 46.70 & 22.10 & 31.19 & 33.17 & 22.63 & 44.20 & 83.39 & 15.93 & 0.68 \\
\hline 38. & 55.56 & 20.27 & 24.17 & 36.33 & 16.95 & 46.71 & 83.41 & 15.64 & 0.94 \\
\hline 39. Е & 48.41 & 22.76 & 28.83 & 33.36 & 21.00 & 45.64 & 80.55 & 19.01 & 0.44 \\
\hline 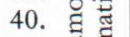 & 52.42 & 23.99 & 23.59 & 33.42 & 17.42 & 49.16 & 80.86 & 18.62 & 0.52 \\
\hline 41. స్తే हี & 65.05 & 25.31 & 9.63 & 29.86 & 7.50 & 62.63 & 82.86 & 16.80 & 0.34 \\
\hline 42. $\sum^{0} \infty$ & 48.00 & 27.00 & 25.00 & 31.52 & 18.96 & 49.52 & 79.95 & 15.56 & 4. 52 \\
\hline 43. & 46.00 & 7.00 & 47.00 & 42.66 & 28.37 & 28.97 & 29.75 & 16.76 & 3.49 \\
\hline & 47.28 & 8.12 & 44.60 & 35.82 & 30.95 & 33.23 & 77.93 & 18.57 & 3.40 \\
\hline 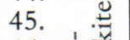 & 51.41 & 7.30 & 41.29 & 33.40 & 29.55 & 37.04 & 75.44 & 20.58 & 3.98 \\
\hline 46. 过 & 54.47 & 8.03 & 37.50 & 37.88 & 25.20 & 36.92 & 80.15 & 17.45 & 2.40 \\
\hline 47. บั & 58.84 & 8.85 & 32.31 & 34.97 & 22.45 & 42.57 & 80.13 & 17.44 & 2.43 \\
\hline 48. तु & 58.50 & 4. 72 & 36.78 & 37.36 & 23.79 & 38.85 & 77.93 & 20.52 & 1.55 \\
\hline 49. ड़ & 62.68 & 7.02 & 30.30 & 36.86 & 20.15 & 42.99 & 78.06 & 18.89 & 3.05 \\
\hline
\end{tabular}

ones by drawing lines parallel to the base $\mathrm{MgO}$ $\mathrm{Fe}_{2} \mathrm{O}_{3}+\mathrm{TiO}_{2}$ which does not help to distinguish between the biotites of igneous and metamorphic-metasomatic rocks. However line drawn parallel to the base $\mathrm{FeO}+\mathrm{MnO}-$
$\mathrm{Fe}_{2} \mathrm{O}_{3}+\mathrm{TiO}_{2}$ clearly separates the biotites of metamorphic-metasomatic rocks from those of igneous rocks. It is interesting to note that the biotites from charnockites fall into the field of metamorphic biotites, a point not tested by 
Heinrich, which is apparent from the groups of rocks considered by him. Further he has treated only the biotites of igneous granites. The present study reveals that the biotites from the metamorphic-metasomatic granites have clearly separated from those of igneous granites (diagram 1). A plot or two not occupying the field concerned, constitute exceptions.

\section{Diagram 2}

This has been constructed on the lines suggested by Nockolds. This diagram was primarily designed by him to bring out the interdependence of the chemical composition of biotite and the nature of the associated ferromagnesian minerals occurring along with it in that rock. Nockolds restricted his observations to the biotites of igneous rocks. Plotting the chemical data of the biotites of metamorphic-metasomatic rocks too, it is seen (diagram 2) that such

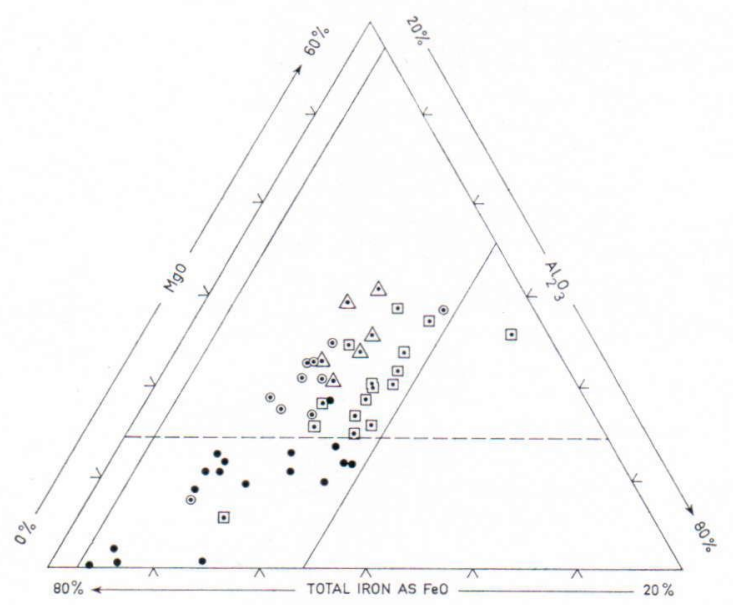

- Biotites from igneous rocks: calc--alkali, alkali \& potassic granites.

- Biotites from metamorphic-metasomatic rocks: granites.

- Biotites from metamorphic-metasomatic rocks: schists \& gneisses.

Biotites from metamorphic-metasomatic rocks: acid charnokites.

Zone demarcated by Nockolds for igneous rocks. Separates biotites of magnatic environment from those of metamorphic-metasomatic environment. biotites occupy the same field as the one occupied by biotites of igneous rocks, eventhough the associated ferromagnesian minerals are entirely different from those found in metamorphic -metasomatic rocks. This diagram however, can be employed to distinguish between the biotites of igneous and metamorphic-metasomatic origin. This can be achieved by drawing a line parallel to the base total iron as $\mathrm{FeO}-\mathrm{Al}_{2} \mathrm{O}_{3}$. Such a line drawn on diagram 2 is seen clearly demarcating the plots of biotites formed under metamorphic-metasomatic environment from those formed under magmatic environment.

\section{Diagram 3}

This diagram was proposed by the present author (1967) in an earlier article. The three oxides $-\mathrm{SiO}_{2}, \mathrm{~K}_{2} \mathrm{O}$ and $\mathrm{Na}_{2} \mathrm{O}$ - were selected as the critical constituents, since it is largely believed that these are the major constituents operative in the process of granitisation. As a consequence, it is reasonable to presume that these three oxides might be at least influencing the chemical composition of biotites formed by metamorphic-metasomatic processes. Surprisingly however, it is immediately noticed from diagram 3, that the biotites formed under different environments are practically identical in respect of the contents of $\mathrm{SiO}_{2}, \mathrm{~K}_{2} \mathrm{O}$ and $\mathrm{Na}_{2} \mathrm{O}$.

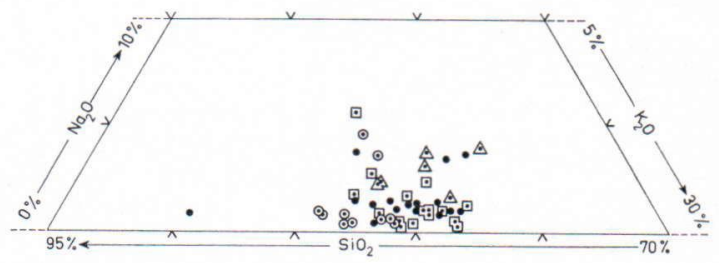

Biotites from igneous rocks: calc-alkali, alkali \& potassic granites.

- Biotites from metamorphic-metasomatic rocks: granites.

Biotites from metamorphic-metasomatic rocks: schists \& gneisses.

- Biotites from metamorphic-metasomatic rocks: acid charnokites. 


\section{Conclusions}

From the foregoing account it is evident that the mineral biotite, plays an important role in distinguishing magmatic and metamorphic-metasomatic rocks and especially the granites. The present study has conclusively proved that the chemical composition of biotites formed under different environments is different. Heinrich eventhough regarded the chemical composition of biotites to indicate the geological occurrence, he however did not distinguish further between the fields of igneous and metamorphic-metasomatic granites. In the present study it is shown, how the processing of chemical data on the lines of Heinrich and on those of Nockolds, can be extended to metamorphic-metasomatic granites and also to charnockites.

Peikert's conclusion that the granites are of metasomatic origin is also arrived at by the present author, by merely processing the chemical composition of biotites occurring in those rocks, on the lines set out in this paper.

Based on several evidences, Naik (1965) advocates a metamorphic-metasomatic origin to the Molakalmuru granites. The biotites occurring in these rocks when treated on the lines given in this paper, it is seen that the biotites and the rocks containing them are formed under metamorphic-metasomatic environment. As already noted, diagram 3 does not show any distinction between the biotites formed under different environments. This phenomenon is especially strange while dealing with the granitised granites, since in this process the major event is one of introduction of potassium into the preexisting rocks. It appears that apparently this action has not affected the $\mathrm{K}_{2} \mathrm{O}$ content of the biotites of such rocks.

Thus it is concluded that the chemical composition of biotites, fluctuates according to the environment of its formation. Chemical evidence by way of $\mathrm{K}$-metasomatism fails to be an index to the genesis of the granites, if the $\mathrm{K}_{2} \mathrm{O}$ content together with those of $\mathrm{SiO}_{2}$ and $\mathrm{Na}_{2} \mathrm{O}$ of the biotites occurring in such rocks are utilized. Peikert has already utilized biotite as a guide to ascertain the origin of granites. The present studies have also indicated that biotite certainly could be looked at as an index mineral in petrogenesis, more so with the granites, since it is the only ferromagnesian mineral occurring in them. Further studies however, are necessary, since the present author has based his observations on only 49 chemical analyses of biotites.

\section{REFERENCES}

DEer, W. A. et al (1962). Rock forming minerals 3, sheet silicates, Longmans, London.

Gokmale, N. W. (1967). Alkali-poor biotites from the Velence Mtn. granites, Hungary. Curr. Sci. Vol. 36, No. 21 pp. $578-579$.

Gorar, M. (1951). Petrological studies on plagioclase twins. A. Min., Vol. 36, pp. 884-901.

HALL, A. J. (1941). Relation between chemical composition and R.I. in the biotites. Am. Min., Vol. 26, pp. $34-41$.

- (1941). Relation between colors and chemical composition in biotites. Am. Min., Vol. 26, pp. 29-33.

Heinrich, E. W. (1946). Studies in mica group; the biotite-phlogopite series. Am. Jour. Sci. Vol. 244, pp. $836-848$.

MACHIGAD, B. S. (1967). Some aspects of garnet-biotite equilibria in enderbites from Pallavaram, Madras. Kar. Univ. Jour. Vol. XII. pp. 25-40.
NAIK, M. S. (1965). The Molakalmuru granites of Chitradurga District, Mysore State. Unpublished Ph. D. thesis submitted to Karnatak University, Dharwar, India.

Nockolds, S. R. (1947). The relation between chemical composition and paragenesis in the biotite micas of igneous rocks. Am. Jour. Sci. Vol. 245, pp. 401-420.

Peikert, E. W. (1963). Biotite variation as a guide to petrogenesis of granitic rocks in the Precambrian of northeastern Alberta. Jour. Petr. Vol. 4, pp. 432-459.

Tertsch, H. (1941). Die optische Orientierung der hochtemperatur Anorthites. Miner. Petr. Mitt. 54.

- (1942). Zur Hochtemperaturoptik basischer Plagioklase. Miner. Petr. Mitt. 54.

Turner, F. J. (1951). Observation of twinning of plagioclase felspars in metamorphic rocks. Am. Min. Vol. 36, pp. $581-590$.

Manuscript received, February 22, 1968. 